\title{
THE ROLE OF EVALUATION AND SELF-EVALUATION IN ACHIEVING STELLAR LEARNING RESULTS IN MATHEMATICS TEACHING
}

\section{Rešić Sead $^{1}$ \\ Edina Alimanović}

Department of Mathematics of Natural Sciences, University of Tuzla Elementary school Brčko

Received: 22.04.2013

Accepted: 25.04.2013
Professional paper

UDC:371.26:51

\begin{abstract}
This paper elaborates the concept of evaluation and self-assessment in the teaching of mathematics and other concepts important to explain the image on the realization winning learning. Also, the essential characteristic that influences this study is education. In a sample of 120 respondents, it was attempted to determine the significance of differences between evaluation and self-assessment in mathematics, in contrary the role of evaluation and self-evaluation in achieving winning learning in mathematics. Analytical - descriptive method and survey method were used in this study, which helped to confirm the hypotheses. The results were shown in tables and graphs and explained with the discussion. The whole operation was rounded with the conclusion.
\end{abstract}

Keywords: evaluation, self-assessment, teaching math.

\section{INTRODUCTION}

The area of this research is primarily upbringing and education. Within these two planes, it is possible to research various phenomena. However, the subject of this paper is "The role of evaluation and self-evaluation in achieving stellar learning results in mathematics teaching" from the students' point of view. In addition, this subject of research is observed from the point of students' perception.
Starting from a critical observation of overall conditions of our schools and education in general, the research in the area of students' achievements encompassed assessment of quality of school achievements.

So far it has not been recorded that a concrete research on this topic has been conducted, so that is also one of the reasons for this paper and thematic.

${ }^{1}$ Correspondence to:

Sead Rešić, Department of Mathematics, Faculty of Natural Sciences, University of Tuzla

Šabana Zahirovića 10, Tuzla, B\&H

Phone:+38761101230

E-mail: sresic@hotmail.com 


\section{THEORETICAL - SCIENTIFIC PROBLEM CONSIDERATION}

\section{Defining the terms consisted in the formulation of the research problem}

Many experts in didactics considered the definition of teaching and its process. Teaching is a unique upbringing-educational system, which takes place under the supervision of the teacher, in a planned and systematic manner, with one relatively fixed group of students, with the aim to educate and up-bring a versatile socialistically developed personality.

If we should pose the question about what kind of process that is, the answer would be: Teaching is a complex, integral and dynamic process aimed at accomplishing educational and up-bringing tasks.

Teaching is the basic guideline in didactics. It is an organized institutional and non-institutional interactive effort towards mastering prescribed content and gaining knowledge, abilities and habits, and enabling students for further permanent work. The aim of teaching is creating a critical, free, autonomous, creative, humane, educated, multicultural, multiethnic and multi-confessional personality in a student, open to all contemporary and future progressive changes in him/herself and society they live in.

Teacher, student and curriculum in teaching form the so-called didactic triangle. If only one of these factors is omitted, that is not teaching any more. Teacher is the one who didactically processes science in order to make it accessible to the student. $\mathrm{He} / \mathrm{she}$ chooses and divides the subject matter, and decides on the extensity and intensity of subject matter examination. Teacher is a qualified expert who organizes an efficient teaching process and directly teaches and leads students for them to obtain knowledge and upbringing.

Teacher is an expert with high working, educational qualities, educated for work in an educational institution.

Contemporary teacher is an organizer and leader in the teaching process, coordinator and mentor, motivator, equal collaborator, etc. His/her primary role is to aid students in developing all their physical and psychological potential, and help them achieve their individual maximum. Contemporary demands still affirm individuals as creative ones and initiators, but now teachers' teamwork is demanded more. Teachers constantly perfect their skills, as to better respond to the new demands of the society.

Also, in order to properly analyze and perform the research, it is necessary to define our examinees, in this case, students. Student is a participant in didactical - communicational creative activities, which are aimed at his/her education, upbringing, integration in the social community and developing an independent, liberated and critical personality. Student is a regular or part-time attendee in a certain form of educational institution. In contemporary didactics he shows up as a subject in the teaching process in all its stages (from planning, through realization, to evaluation).

Assessment or evaluation are considered synonymous. Evaluation implies determining relative value of something according to an adopted standard. Assessment in teaching - in didactic literature there are various expressions, such as teaching evaluation, valorization, grading, assessment, follow-up, self-evaluation, etc. In school docimology there are external and internal evaluation. The external evaluation refers to grades of subjects outside of school, values of a school or overall pedagogic achievements of students from a certain school. The internal evaluation encompasses monitoring, grading and leading students during the teaching process. This activity is intertwined with numerous other teaching activities, and implies self-monitoring and self-evaluation of students. Achievement in the teaching process is demonstrated through beforehand decided signs (percentages, scales, descriptive, numeric,...). Students' self-evaluation can be achieved via numerous criteria. For efficiency of work on the subject matter, the best is the system of scoring the achievements. However, it is very important that students evaluate themselves in relation to how they learn, are some of their goals contradictory to learning, and so on. Here, I will briefly elaborate on some chosen aspect of students' self-evaluation, and those are: 1) scoring achievements, 2) academic control, 3) aim orientations, 4) learning strategies, 5) anger management, 6) power as a child's need.

\section{RESEARCH METHODOLOGY Research proposition}

Research proposition is "The role of evaluation and self-evaluation in achieving stellar learning results in mathematics teaching", that is, how to make every student a success in a simple way. This is a current topic today; it has been spoken about and still is. The importance of this topic reflects in how certain students are neglected and not allowed to demonstrate their knowledge. 
Students' achievement as one of the basic categories and pillar of good and successful education is reflected in results of successfully realized and personalities prepared for life.

\section{Aim of the research}

The aim of the research is to ascertain, examine, analyze and interpret whether students notice that different types of evaluating students in mathematics classes influences the students' relation toward work, do students who have been evaluated rightfully treat work more responsibly, and whether self-evaluation and evaluation of students is at the same level.

\section{Research tasks}

The above-mentioned aim yields research tasks, which are to examine examinees' attitude towards the following questions:

1. Examine if evaluation of students in mathematics teaching varies

2. Examine if evaluation in class affects the student's relation toward work

3. Do those students who are evaluated rightfully relate to work differently

4. Is self-evaluation and evaluation of students on the same level

\section{Hypotheses}

\section{Main hypothesis}

The presupposition is that correlation between evaluation and self-evaluation of students exists. Presuppositions are also as follows: there are discrepancies in students' work assessment; evaluating students during mathematics classes affects their relation toward work; it is supposed that those students who were rightfully evaluated approach work with more responsibility; students pay more attention to teachers who evaluate work justly (correlation between evaluation and self-evaluation).

\section{Sub-hypotheses}

1. It is presupposed that variety in student evaluation in mathematics teaching exists

2. It is presupposed that evaluating students during class affects their relation towards work

3. It is presupposed that those students who were evaluated justly have a more responsible relation toward work

4. It is presupposed that students pay more attention to teachers who are fair while evaluating work (correlation between evaluation and selfevaluation)

\section{Population and sample}

The population in this research consists of elementary school students in District Brčko.

The sample comprises of I, II, III, IV and V (first, second, third, fourth and fifth) grade students. 120 examinees were included.

\section{Methods and techniques}

In this research analytic - descriptive method and survey method were employed.

When it comes to techniques, questionnaire technique was used. It consisted of 10 questions.

The research was anonymous. The instrument used was a questionnaire especially composed for this research called "The role of evaluation and self-evaluation in achieving stellar (making every students a success)".

\section{Course and calendar of the research}

The research was conducted in the period between 01/02/2013 (Friday) and 28/02/2013 (Thursday).

A parent-teacher conference was organized at the school, where parents were familiarized with the preventive program and details of its conduction, which included consent from the parents for allowing their children to participate in the research. Everybody was assured of anonymity and privacy of gathered data.

\section{ANALYSIS AND INTERPRETATION OF RE- SEARCH RESULTS}

In this chapter I analyzed qualitatively and quantitatively, as well as interpreted, data and results I gathered through the research of this topic.

The manner in which research findings are presented, i.e. data and results, is through text, tables and graphs. The research encompassed 120 examinees. 
Variability of evaluation of students in mathematics teaching

It is supposed that there is variability in evaluating viewed students whether the grade for self-evaluation students in mathematics teaching. In this task I interand evaluation is the same, and their response is:

\begin{tabular}{llll}
\hline & & $\mathrm{f}$ & $\%$ \\
\hline a) & Often & 24 & 20,00 \\
b) & Sometimes & 42 & 35,00 \\
c) & Never & 54 & 45,00 \\
\hline
\end{tabular}

Table 1 represents frequency (f) and percentages of results about equality of students' self-evaluation and evaluation. They responded: often -24 examinees, that is $20 \%$; sometimes -42 examinees, that is $35 \%$; never - 54 examinees, that is $45 \%$.

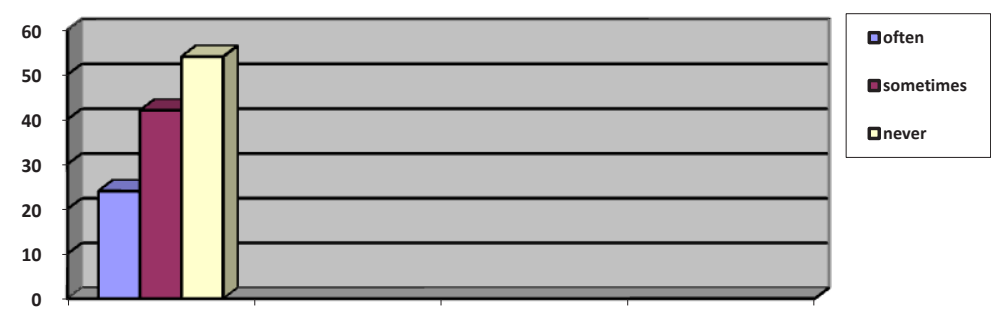

Graph 1 shows clearly how many examinees responded to the question posed, and their answers are presented.

The following area of interest was whether teachers make mistakes while grading students and how that happens. I believe that teachers do make mistakes while evaluating students. Examinees responded as follows:

\begin{tabular}{llllllc}
\hline & \multicolumn{2}{l}{ Often } & \multicolumn{2}{l}{ Sometimes } & \multicolumn{2}{l}{ Never } \\
& $\mathrm{f}$ & $\%$ & $\mathrm{f}$ & $\%$ & $\mathrm{f}$ & $\%$ \\
Due to classroom noise & 9 & 7,50 & 3 & 2,50 & 8 & 6,66 \\
Teacher is nervous & 10 & 8,33 & 9 & 7,50 & 8 & 6,66 \\
Antipathy towards student & 18 & 15,00 & 8 & 6,66 & 3 & 2,50 \\
Sympathy towards student & 26 & 21,66 & 8 & 6,66 & 8 & 6,66 \\
Other reasons & 2 & 1,66 & 0 & 0 & 0 & 0 \\
\hline
\end{tabular}


Table 2 presents attitudes of students regarding errors teachers make while evaluating. The reason for their wrong grades was frequently classroom noise, according to 9 examinees $(7.50 \%)$; sometimes 3 examinees $(2.50 \%)$ and never for 8 examinees $(6.66 \%)$. Examinees say that the reason why they get bad grades in some cases is the teacher being nervous, for 10 examinees often $(8.33 \%)$, sometimes for 9 of them
(7.50\%), never for 8 examinees (6.66\%). Antipathy towards student is the reason often for 18 examinees $(15 \%)$, sometimes for $8(6.66 \%)$, never for 3 examinees $(2.50 \%)$. Sympathy toward student is the reason for 26 examinees often $(21.66 \%)$, sometimes for 8 of them $(6.66 \%)$, never for 8 examinees $(6.66 \%)$. For other reasons 2 examinees said often $(1.66 \%)$, none opted for sometimes and never.

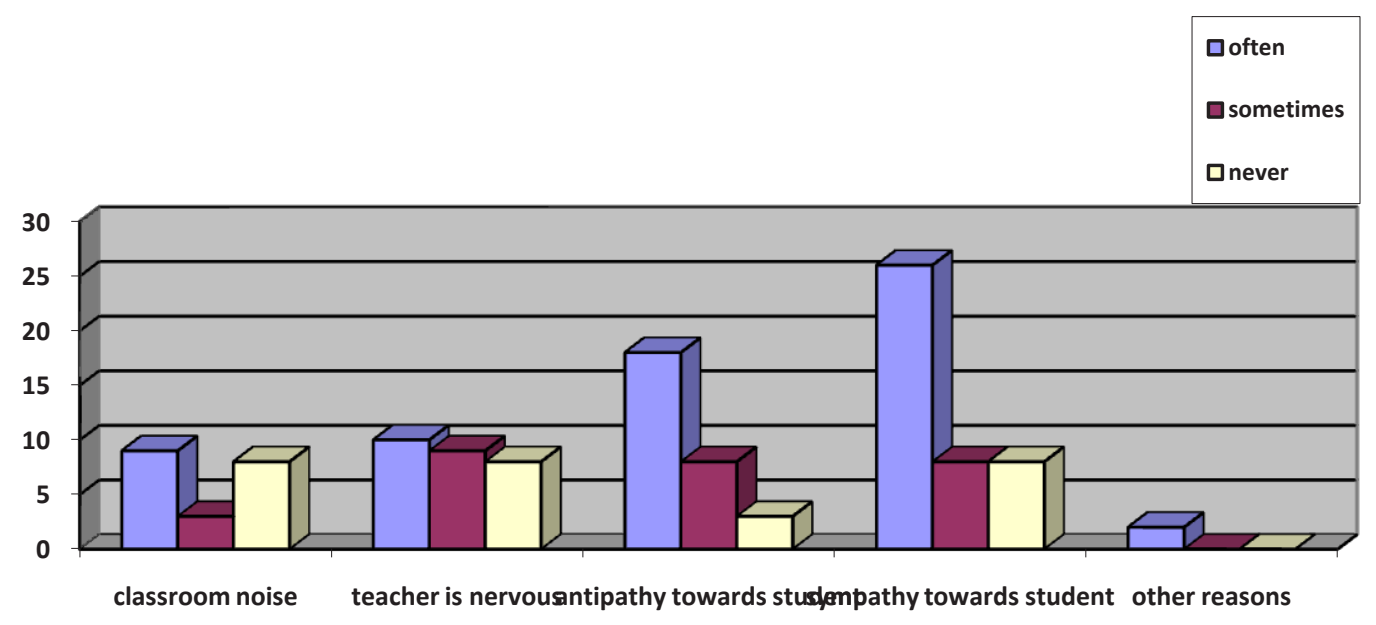

Graph 2 shows the reasons for possible error in grading. Also, examinees reported other reasons, such as:

Private problems

Teachers look at other subjects and grades

Disturbances in the family

Problems with colleagues
Based on the first questions in the survey, the first hypothesis is confirmed and proved in tables and graphs.

Evaluation of students in class affects the student's relation towards work

The assumption is that evaluating students in class affects their relation towards work. In the cases of selfevaluation followed by evaluation, I was interested whether those grades are in concurrence. Therefore my first question in the second task was: Is the grade for knowledge equal to the grade given in the school $\log$ ?

To the question referring to when the teacher evaluates them, students replied:

\begin{tabular}{lll}
\hline & $\mathrm{f}$ & $\%$ \\
\hline They will reduce my grade & 66 & 55,00 \\
If I do not know something, they will help me & 7 & 5,83 \\
They will increase my grade & 11 & 9,16 \\
I will get the grade I studied for & 36 & 30,00 \\
\hline
\end{tabular}


Table 3 shows the role of evaluating students, which represents their relation toward work. The results for this question are: teacher will reduce the grade for 66 examinees $(55.00 \%)$, if they do not know something, teacher will help - 7 examinees $(5.83 \%)$, teacher will increase the grade for 11 examinees $(9.16 \%)$, and they will get the grade they studied for is correct for 36 students $(30.00 \%)$.
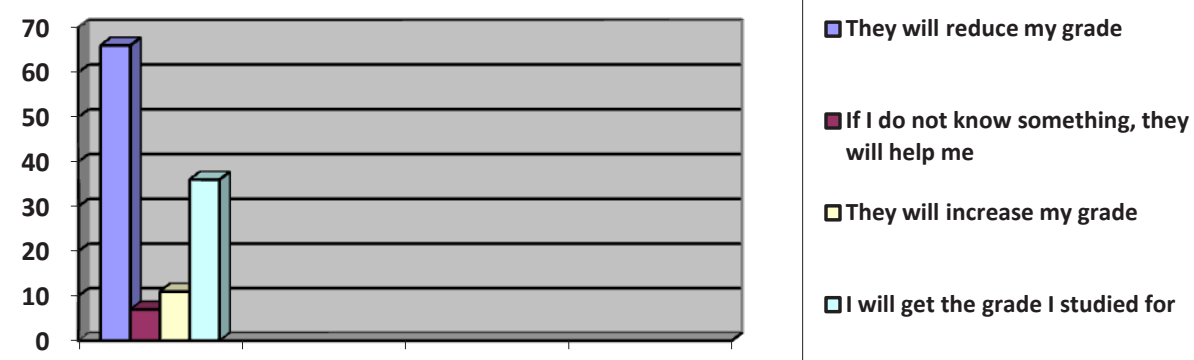

Graph 3 shows the relation of students toward work depending on the role of evaluating.

Evaluation of teachers' attitude toward students - my teacher brings tests, that is, whether they know in adfollowing question was how students react when vance what the results will be. They responded:

\begin{tabular}{lll}
\hline & $\mathrm{f}$ & $\%$ \\
\hline I know exactly what grade each student will get & 23 & 19,16 \\
Only teacher's favorites will get the excellent grades & 61 & 50,83 \\
$\begin{array}{l}\text { It is important to me that teacher will always give me } \varepsilon 36 \\
\text { good grade }\end{array}$ & 30,00 \\
\hline
\end{tabular}

As is seen in Table 4, examinees responded that they know exactly what grade each student will get -23 examinees $(19.16 \%)$, that only teacher's favorites will get excellent grades -61 examinee $(50.83 \%)$ and that it matters to them only that teacher will always give them a good grade $-36(30.00 \%)$.
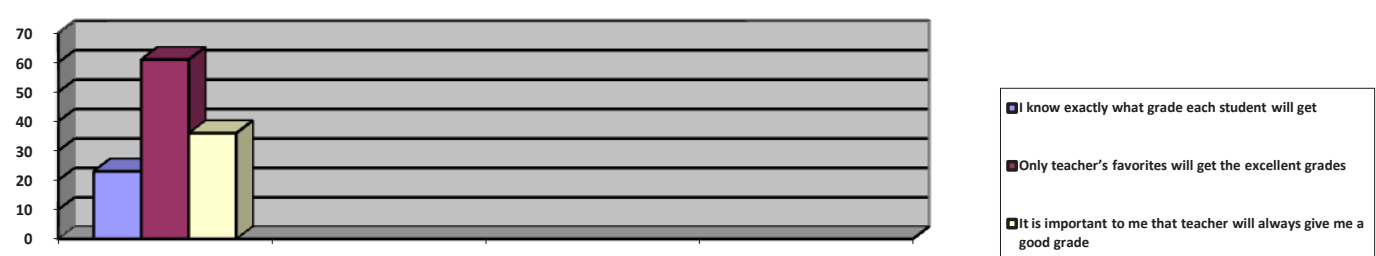

We can precisely see the relation of examinees in teacher's attitude toward their knowledge. Graph 4, where they responded to the question about 
For the question about experience of the subject is the opinion of students' experience with teachers where teacher is correct while grading students: here who evaluate work unjustly:

\begin{tabular}{lll}
\hline & $\mathrm{f}$ & $\%$ \\
\hline Frivolous & 81 & 67,50 \\
Irrelevant subject & 18 & 15,00 \\
Relevant subject & 18 & 15,00 \\
Difficult subject matter & 3 & 2,50 \\
\hline
\end{tabular}

Answers to this question can be seen in Table 5; nees (15.00\%), a relevant subject also by 18 of them this subject is considered frivolous by 81 exami- $(15.00 \%)$ and a difficult subject matter by 3 examinee $(67.50 \%)$, as irrelevant subject by 18 exami- nees $(2.50 \%)$.
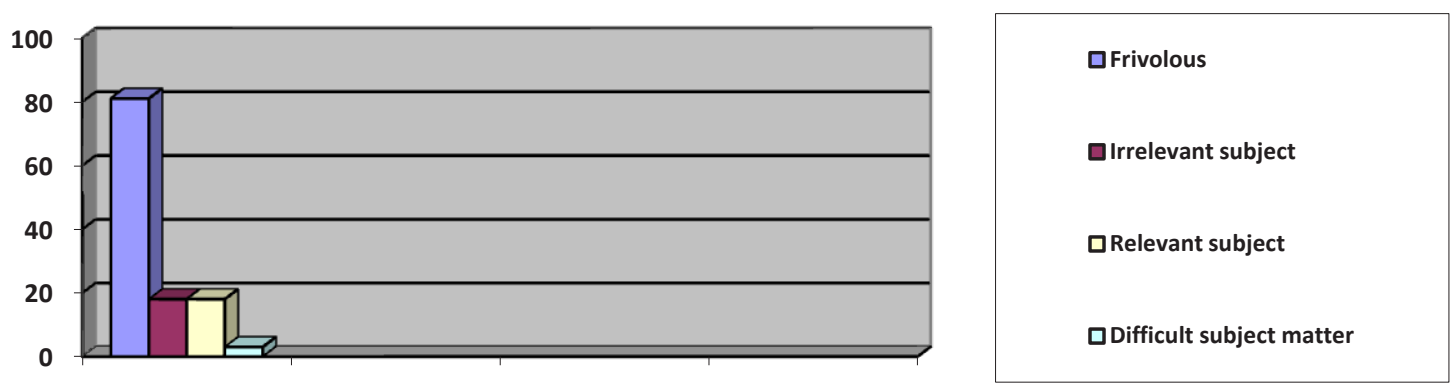

We can see in Graph 5 how many examinees responded in a certain way to offered options. Therefore it is obvious that over 80 examinees, over $50 \%$, opted for the first answer.

The second hypothesis is completely accurate, since $I$ acquired the assumed response from survey questions. The second hypothesis is confirmed.
Students act more responsibly towards work when they are justly graded

The assumption is that student treat work more responsibly when they are evaluated in a just manner.

My following question is whether students disregard the subject of teachers where they know in advance that they cannot get a positive grade.

Therefore, I wanted to find out how often students disregard the subject of teachers where they already know in advance that they cannot get a positive grade.

\begin{tabular}{lll}
\hline & $\mathrm{f}$ & $\%$ \\
\hline Often & 61 & 50,83 \\
Sometimes & 44 & 36,66 \\
Never & 10 & 8,33 \\
\hline
\end{tabular}


From Table 6 we can see the results from examinees, that is, whether they disregard the subject of teachers where they already know in advance that they cannot get a positive grade: often for 61 examinees $(50.83 \%)$, sometimes for 44 of them $(36.66 \%)$ and 10 examinees say never $(8.33 \%)$.
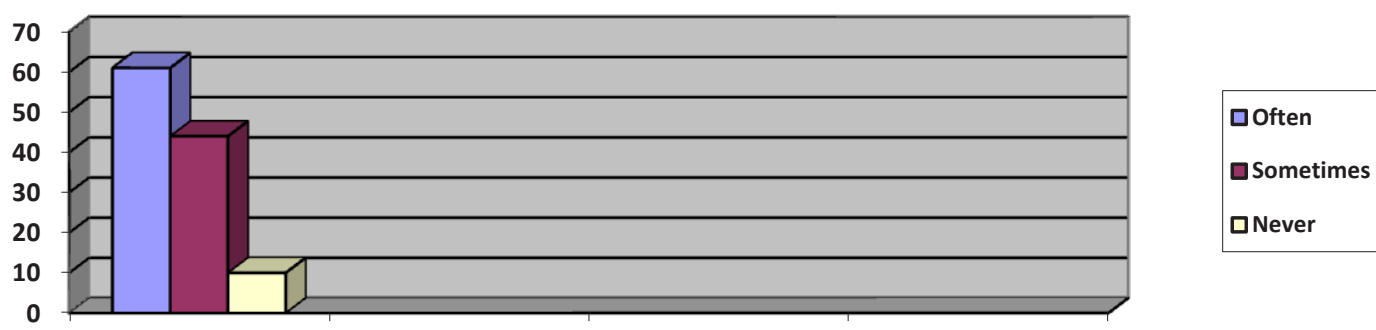

Graph 6 demonstrates that over 60 examinees opted for one, i.e. first offered answer. Results show that most examinees often disregard the subject of the teacher who is not present in class.

My third hypothesis is confirmed. Based on the questions the sub-hypothesis is also confirmed, which implies the confirmation of the hypothesis.
Students pay more attention to teachers who are correct while grading

The assumption is that students pay more attention to teachers who are correct while grading (connection between evaluation and self-evaluation).

My following question regards the reactions of students; how they react when they cannot get a positive grade.

Examinees stated that in a situation when they cannot get a positive grade, they react as follows:

\begin{tabular}{llllllcc}
\hline & \multicolumn{2}{l}{ Often } & \multicolumn{3}{l}{ Sometimes } & \multicolumn{2}{l}{ Never } \\
& \multicolumn{1}{l}{ f } & $\%$ & $\mathrm{f}$ & $\%$ & $\mathrm{f}$ & $\%$ \\
I am not going to class next time. & 19 & 15,83 & 10 & 8,33 & 4 & 3,33 \\
I am not active the following class. & 26 & 21,66 & 8 & 6,66 & 10 & 8,33 \\
I consult the subject teacher. & 13 & 10,83 & 23 & 19,16 & 7 & 5,83 \\
& & & & & &
\end{tabular}

In table 7 it is shown whether examinees react at all and, if so, how, when they cannot get a positive grade. 19 examinees declared that they often do not go to class next time $(15.83 \%)$, sometimes 10 of them $(8.33 \%)$, never 4 examinees $(3.33 \%)$. They are not active the following class: often 26 examinees $(21.66 \%)$, sometimes for 8 of them $(6.66 \%)$ and 10 say never $(8.33 \%)$. They consult the subject teacher - often for 13 examinees (10.83\%), sometimes 23 of them $(19.16 \%)$ and never for 7 examinees $(5.83 \%)$.
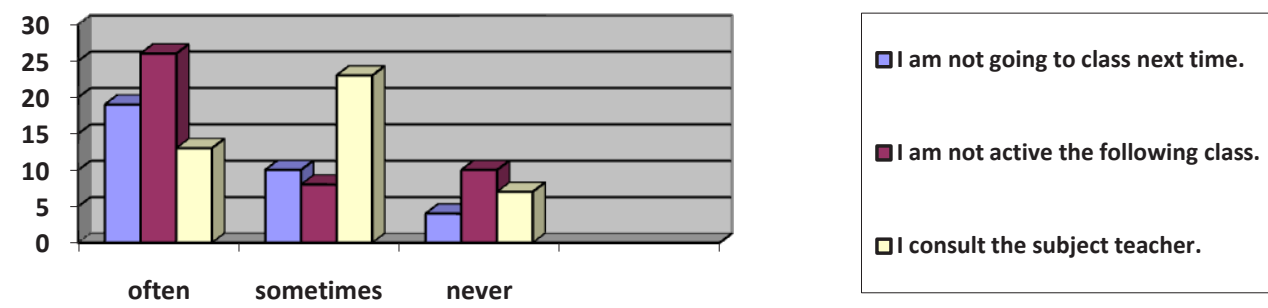
The graph shows exactly how students react and if they react at all when they cannot get a positive grade, so we can see that most of them responded that they are not active in the following class, in order to get back to the teacher.
With this question, I also wanted to find out how students treat the teacher.

To the question whether a teacher who does not grade knowledge deserves a responsible relation of the student toward their subject and work, students replied:

\begin{tabular}{lcc}
\hline & $\mathrm{f}$ & $\%$ \\
\hline I agree & 94 & 78,33 \\
I partially agree & 17 & 14,16 \\
I disagree & 9 & 7,50 \\
\hline
\end{tabular}

From the table we can see the results regarding the question whether a teacher who does not grade knowledge deserves a responsible relation of the student to- ward their subject and work. That they do not deserve it, most examinees agree, 94 of them (78.33\%), 17 of them partially agree (14.16\%), 9 disagree $(7.50 \%)$.
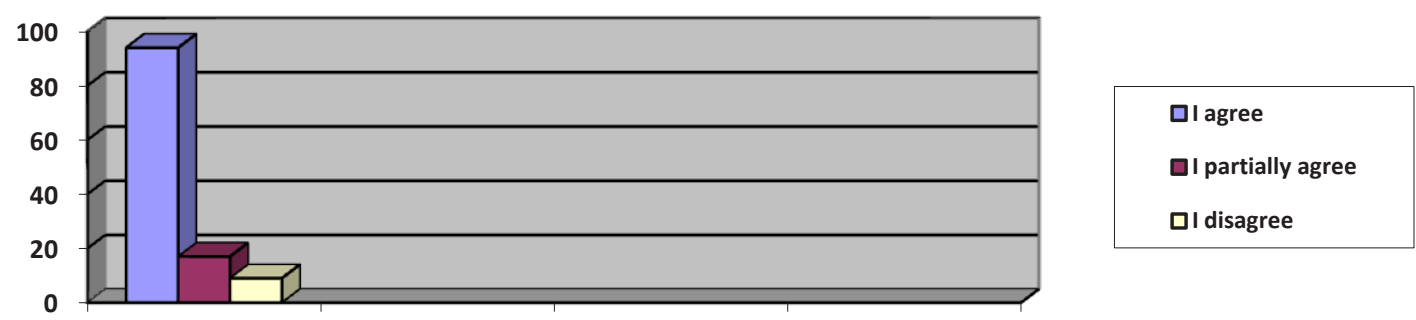

It is visible from the graph that over 80 examinees responded that a teacher who does not grade knowledge does not deserve a responsible relation of the student toward their subject and work.
However, I was also interested in what emotions a teacher who grades knowledge induces. Responses were:

\begin{tabular}{lll}
\hline & $\mathrm{f}$ & $\%$ \\
\hline Attention & 15 & 12,50 \\
Responsibility & 19 & 15,83 \\
Commits me to work & 22 & 18,33 \\
Respect & 64 & 53,33 \\
\hline
\end{tabular}

Table 9 shows that the teacher who grades knowledge invokes emotions: attention for 15 examinees $(12.50 \%)$, responsibility for $19(15.83 \%)$, commit- ment to work for 22 examinees $(18.33 \%)$ and respect for 64 examinees $(53.33 \%)$. 


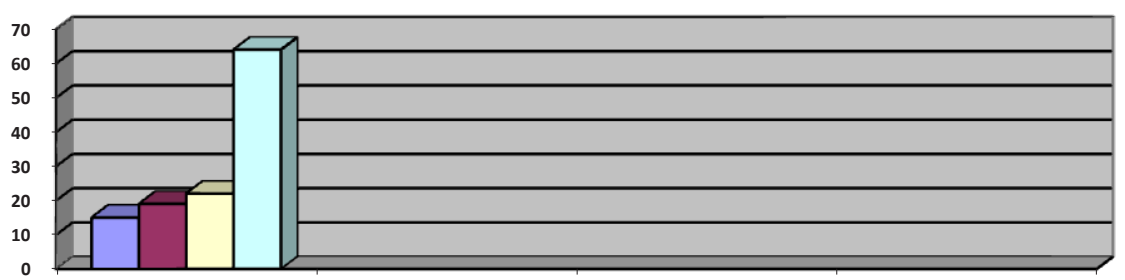

It is visible from the graph that most examinees responded that teacher who grades knowledge invokes the feeling of respect, and then responsibility, commitment for work and attention.
Besides this, I was also interested which feelings are evoked by teacher who grades everything but knowledge.

These are the responses to this question:

\begin{tabular}{lll}
\hline & $\mathrm{f}$ & $\%$ \\
\hline Lack of attention & 10 & 8,33 \\
Irresponsibility & 24 & 20,00 \\
I am not committed to work & 18 & 15,00 \\
Disrespect & 68 & 56,66
\end{tabular}

Table 10 shows what feelings examinees have to- irresponsibility 24 of them $(20.00 \%)$, no commitment wards teachers who grade everything but knowledge. to work for 18 examinees (15\%) and disrespect for 68 So, 10 examinees exhibit lack of attention $(8.33 \%)$, examinees $(56.66 \%)$.

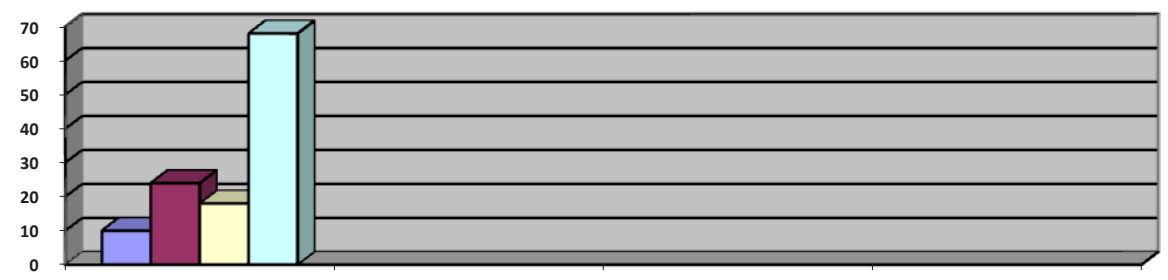

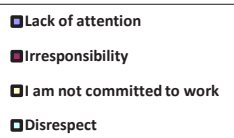

DDisrespect
Graph 10 shows that most examinees replied that teacher who grades everything but knowledge invokes feelings of disrespect, follows by irresponsibility, no commitment to work and lack of attention.

Fourth hypothesis is confirmed because of the questions which gave us the desired answer and confirmed sub-hypotheses, so we can confirm that fourth hypothesis is correct.

\section{CONCLUSIONS}

I would like to point out that the hypothesis is confirmed, that is, there is a connection between students' evaluation and self-evaluation in achieving stellar learning - leading the student toward success.
- Most examinees have faced the problem of evaluating and self-evaluating knowledge.

- Examinees stated that teachers make mistakes while grading mostly due to sympathy or antipathy towards students.

- They believe that when they learn the subject matter and teacher evaluates their knowledge, they will give them a lower grade.

- Most examinees stated that when teacher brings tests, only the favorites would get excellent grades.

- Examinees do not take seriously a subject if teacher is not fair while grading students.

- Over $50 \%$ of examinees disregard a subject if they know they cannot get a positive grade because of the teacher. 
- Reactions of examinees when they get a lower grade than they deserve are not to go to class next time or not to be active in class.

- Most examinees claim, that is, agree that teacher who does not grade knowledge does not deserve a responsible relationship between students and their subject and work.

- According to responses of examinees, teacher who grades knowledge invokes feelings of respect.

- In addition, teacher who grades everything but knowledge invokes feelings of disrespect.

\section{REFERENCES}

Furlan, I. (1970). Upoznavanje, ispitivanje $i$ ocjenjivanje učenika, Zagreb.

Glasser, W. (1994). Kvalitetna škola, Zagreb.

Glasser, W. (1999). Nastavnik u kvalitetnoj školi, Zagreb.

Gojkov, G. (1997). Dokimologija, Beograd.

Grgin, T. (1994). Školska dokimologija, Jastrebarsko.

Matijević, M. (2004). Ocjenjivanje u osnovnoj školi, Zagreb.

Mužić, V. i Vrgoč, H. (2005.) Vrjednovanje u odgoju i obrazovanju, Zagreb.

Poljak, V. (1991). Školska knjiga, Zagreb.

Suljkić, M. (2007). Zbornik radova Filozofskog fakulteta, Tuzla.

Suzić, N. (2005). Pedagogija za XXI vijek, Banja Luka.

Tomić R. (2008). Didaktika, Tuzla.

www.google.ba 